\title{
Water Use Dynamics of Peach Trees under Postharvest Deficit Irrigation
}

\author{
Dong Wang (Corresponding author)
}

USDA, Agricultural Research Service, San Joaquin Valley Agricultural Sciences Center, Water Management Research Unit, 9611 S. Riverbend Ave., Parlier, CA, 93648-9757, USA

Received: August 23, 2015 Accepted: September 19, 2015 Published: September 26, 2015

doi:10.5296/jas.v4i1.8364 URL: http://dx.doi.org/10.5296/jas.v4i1.8364

\begin{abstract}
Postharvest deficit irrigation is a potential strategy for conserving valuable fresh water for production of early season tree fruit crops such as peaches. However, water use dynamics under deficit irrigation conditions that can be described as seasonal changes in crop evapotranspiration $\left(\mathrm{ET}_{\mathrm{c}}\right)$ and crop coefficient $\left(\mathrm{K}_{\mathrm{c}}\right)$ are largely unknown. A three-year field study was carried out in a 1.6 ha peach orchard to determine seasonal $\mathrm{ET}_{\mathrm{c}}$ and $\mathrm{K}_{\mathrm{c}}$ characteristics. The orchard was divided equally into 72 plots, in which 12 randomly selected plots received deficit irrigation and the remaining 60 plots received full irrigation. A Bowen ratio flux tower was installed in the orchard to make meteorological measurements for estimating an integrated $\mathrm{ET}_{\mathrm{c}}$ for the orchard. The study showed that from July to August $75-85 \%$ of the daily net radiation was used by latent heat or partitioned into $\mathrm{ET}_{\mathrm{c}}$. The average monthly cumulative $\mathrm{ET}_{\mathrm{c}}$ was $151 \mathrm{~mm}$ in June, $162 \mathrm{~mm}$ in July, and $155 \mathrm{~mm}$ in August. $\mathrm{K}_{\mathrm{c}}$ values under deficit irrigation conditions or termed as Deficit_ $\mathrm{K}_{\mathrm{c}}$ was computed as ratios of the $\mathrm{ET}_{\mathrm{c}}$ over potential evapotranspiration or $\mathrm{ET}_{\mathrm{o}}$, and were compared with $\mathrm{K}_{\mathrm{c}}$ derived from a lysimeter study under non-water stressed conditions or termed as Lysimeter_ $\mathrm{K}_{\mathrm{c}}$. The maximum Deficit_K $\mathrm{K}_{\mathrm{c}}$ values were $0.90,1.03$, and 1.07 for the three field seasons but all were smaller than 1.20 , the maximum Lysimeter_ $\mathrm{K}_{\mathrm{c}}$. The study demonstrated that water stress under deficit irrigation can be characterized in $\mathrm{K}_{\mathrm{c}}$ values. The approach may be used to detect if portions of an orchard or the entire orchard are under water stress. Conversely, the method may provide guidance on deploying deficit irrigation practices with pre-determined Deficit_Kc.
\end{abstract}

Keywords: Bowen ratio, Potential evapotranspiration, Prunus persica L., Water stress 


\section{Introduction}

The recent episodic and wide-spread drought in the United States highlights the importance of reliable fresh water supplies for agricultural production especially in the arid and semi-arid regions such as the Central Valley of California. Although total farmed land area in California decreased from 11.75 million ha in 1992 to 10.25 million ha in 2010, irrigated agricultural land area increased from 3.08 million ha in 1992 to 3.24 million ha in 2010 (Klonsky, 2012). Moreover, during the eight year time span farm lands cropped with orchards increased from 0.89 to 1.13 million ha because of the high cash values and consumer demands. Among the significant land areas for orchard crops about 23,000 ha are peaches primarily grown in the Central Valley of California. Like in all other orchard crops, growing peaches in the Valley depends on irrigation to meet crop water demand by the peach trees.

For early ripening varieties of peaches, e.g. harvested in late May to early June, deficit irrigation may be used to reduce water use during the postharvest non-fruit bearing periods, e.g. June to August when the crop water demand is the highest. From 1992 to 2010, the annual total amount of potential evapotranspiration required for the area ranges from 1200 to $1400 \mathrm{~mm}$ and the peak water use periods of June to August three month totals averaged 582 $\mathrm{mm}$, which accounts for approximately $45 \%$ of the annual crop water use (CIMIS, 2013). Therefore there is great potential for adopting water saving technologies such as deficit irrigation during the non-fruit bearing summer months. Also, perennial crops such as fruit trees are suitable candidates for applying deficit irrigation strategies because of deeper and more extensive root systems than most annual crops (Costa et al., 2007; Fereres and Soriano, 2007; Girón et al., 2015). Various studies have been reported with respect to physiological and yield responses of peach trees using deficit irrigation and indicated substantial water savings without significantly impacting the yield and fruit quality (Chalmers et al., 1981; Johnson et al., 1992; Goldhamer et al., 1999; Girona et al., 2005; Falagán et al., 2015).

To practice deficit irrigation, it is important to know the actual crop water needs, which can be determined as crop evapotranspiration $\left(\mathrm{ET}_{\mathrm{c}}\right)$ or the amount of water needed to replenish water lost by $\mathrm{ET}_{\mathrm{c}}$. Determination of $\mathrm{ET}_{\mathrm{c}}$ can be done with direct field measurement using in-situ weighing lysimeters (Dugas et al., 1985; Howell et al., 1985; Johnson et al., 1992); micrometeorological energy balance approaches such as the Bowen ratio method (Fuchs and Tanner, 1970; Angus and Watts, 1984; Heilman et al., 1994; Teixeira et al., 2007), the eddy covariance method (Baldocchi, 1988; Testi et al., 2004; Paco et al., 2006), and the surface renewal method (Paw et al., 1995; Castellvi and Snyder, 2009); or the FAO crop coefficient $\left(\mathrm{K}_{\mathrm{c}}\right)$ method, e.g. multiplying theoretical potential evapotranspiration or $\mathrm{ET}_{\mathrm{o}}$ with a plantdependent crop coefficient $\left(\mathrm{K}_{\mathrm{c}}\right)$ value to determine $\mathrm{ET}_{\mathrm{c}}$ for a particular crop at a particular growth stage (Doorenbos and Pruitt, 1977; Allen et al., 1998). Once a reasonable estimate is made on $\mathrm{ET}_{\mathrm{c}}$, the challenge is to determine how much deficit to use and methods of monitoring plant water status without over stressing the plants. One approach for choosing deficit is to pre-select a fraction of $\mathrm{ET}_{\mathrm{c}}$ as the irrigation target, such as replenishing only $50 \%$ $\mathrm{ET}_{\mathrm{c}}$ using irrigation water. Other possibilities include taking a fraction of $\mathrm{K}_{\mathrm{c}}$, especially during peak water use periods such as in the summer months (June - August) for peach trees. This would be another way of implementing deficit irrigation and reducing irrigation amounts 
needed for essential physiological needs but not fully meeting the crop $\mathrm{ET}_{\mathrm{c}}$ requirement.

The objective of this study was to characterize water use or $\mathrm{ET}_{\mathrm{c}}$ and $\mathrm{K}_{\mathrm{c}}$ dynamics of a peach orchard in a three year field experiment when the orchard was managed under postharvest deficit irrigation. Irrigation decisions were based on $\mathrm{ET}_{\mathrm{c}}$ estimates using real time $\mathrm{ET}_{\mathrm{o}}$ and literature $\mathrm{K}_{\mathrm{c}}$ values derived from an earlier lysimeter study. Because only portions of the orchard received deficit irrigation and majority received full irrigation, the overall orchard-wide $\mathrm{ET}_{\mathrm{c}}$ was estimated with an approximate Bowen ratio method with instrument tower installed in the orchard downwind from the dominant wind direction. An orchard-wide $\mathrm{K}_{\mathrm{c}}$ was determined to reflect the effect of deficit irrigation.

\section{Materials and Methods}

\subsection{Field Description and Deficit Irrigation Treatment}

Field studies were carried out from 2008 to 2010 in a 1.6 ha mature peach orchard located near Parlier, California, USA. The trees were early-ripening "Crimson Lady" (Prunus persica (L.) Batsch) on "Nemaguard" rootstock planted in April 1999 (Bryla et al., 2005). Each year, the peaches were harvested in late May to early June. The dimension of the orchard was 122 $\mathrm{m}$ in the east - west direction and $133 \mathrm{~m}$ in the north -south direction, with individual trees spaced $1.8 \mathrm{~m}$ apart within rows (in the north-south direction) and $4.9 \mathrm{~m}$ between rows (in the east-west direction). The orchard was laid out for irrigation studies using furrow, drip, and micro-sprinkler irrigation systems and equally divided into 72 irrigation plots with each plot consisted of 24 trees in three rows with eight trees per row per plot (Figure 1). A border row and a border tree in each row were used on each side or end of the orchard. The soil at the field site is a Hanford sandy loam soil (coarse-loamy, mixed, thermic Typic Xerorthents).

During the three year field experiment, 12 out of the 72 irrigation plots received postharvest deficit irrigation and the remaining 60 plots received full irrigation (Figure 1). The deficit irrigation treatment plots included 6 furrow irrigation plots and 6 drip irrigation plots to replace a portion of the crop evapotranspiration $\left(\mathrm{ET}_{\mathrm{c}}\right)$. For the furrow deficit irrigation, a watering event was initiated when stem water potential approached $-2 \mathrm{MPa}$. For the drip deficit irrigation, only one fourth of the full amount of $\mathrm{ET}_{\mathrm{c}}$ was applied during each irrigation event. To guide irrigation decisions, the values of daily $\mathrm{ET}_{\mathrm{c}}$ were determined by multiplying real-time values of potential evapotranspiration $\left(\mathrm{ET}_{\mathrm{o}}\right)$ with literature crop coefficients (Lysimeter_K $\mathrm{K}_{\mathrm{c}}$ or Lys_K $\mathrm{K}_{\mathrm{c}}$ ) developed for the same peach variety from an adjacent orchard using a large underground weighing lysimeter (Johnson et al., 2005).

\subsection{Meteorological and Energy Balance Measurements}

To provide on-site $\mathrm{ET}_{\mathrm{c}}$ estimates, a modified Bowen ratio system was deployed in the orchard. Because the predominant wind was from the northwest direction, the system tower was installed near the southeast corner of the orchard approximately $138 \mathrm{~m}$ downwind from the northwest corner of the orchard (Figure 1). Also because the tree heights can increase significantly during each year, a telescoping pole of $5.1-\mathrm{cm}$ diameter galvanized steel pipe fitted in a 7.6- $\mathrm{cm}$ diameter steel pipe as the base was installed within a tree row to minimize interferences with orchard management, e.g. annual pruning, chemical spray, etc. 


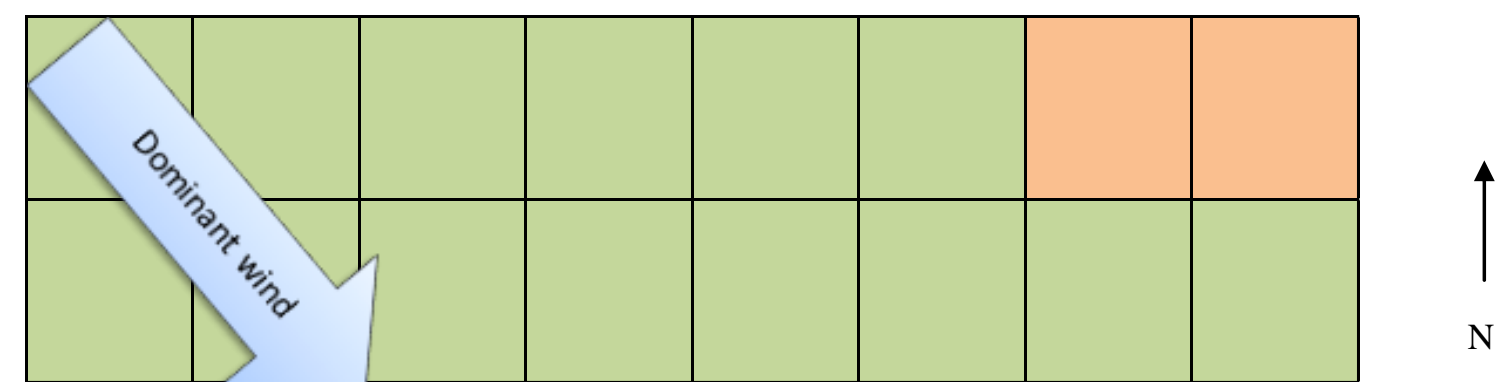

Figure 1. Schematic of peach orchard lay-out (Green = nondeficit irrigation; Orange = deficit irrigation), tower location, and dominant wind direction. Orchard dimension $=122 \mathrm{~m}$ (east-west) by $133 \mathrm{~m}$ (north-south)

Sensors were mounted on two $1.9-\mathrm{cm}$ diameter aluminum cross beams on the telescoping pole, placed at two heights separated by $2 \mathrm{~m}$ distance: the lower beam at canopy level, upper beam at $2 \mathrm{~m}$ above the canopy. The pole was raised periodically during each growing season to maintain the lower beam within $\pm 15 \mathrm{~cm}$ of the top of the average canopy height.

The tower site consisted of a set of meteorological and soil sensors for energy balance measurements. Sensors mounted on the upper beam included a LI-COR silicon pyranometer 
for solar radiation (LI200X, Campbell Scientific, Inc., Logan, $\mathrm{UT}^{1}$ ), a net radiometer for net radiation $\left(Q^{*} 7\right.$, Radiation and Energy Balance Systems, Seattle, WA), an air temperature and relative humidity sensor (Vaisala HMP 45C, Campbell Scientific, Inc., Logan, UT), and an R.M. Young Wind speed and direction sensor (model 05103, Campbell Scientific, Inc., Logan, UT). Sensors mounted on the lower beam included an air temperature and relative humidity sensor (Vaisala HMP 45C, Campbell Scientific, Inc., Logan, UT) and a Met One wind speed and direction set (model 034B, Campbell Scientific, Inc., Logan, UT).

To account for partial ground shading from the tree canopy, the soil heat flux was measured with three heat flux plates (HFT3, Radiation and Energy Balance Systems, Seattle, WA), all buried at $1 \mathrm{~cm}$ depth: the first one located in the tree row half way between two adjacent trees, the second one located half way between two adjacent tree rows, the third one was at half distance between the first and second plates. An arithmetic average from the three plates was used to represent the soil heat flux in energy balance calculations. In addition to the heat flux measurement, six type T copper - constantan thermocouples were installed at the tower site for soil temperature measurements. They were located at the same relative distances to the tree and tree rows as the heat flux plates (but $10 \mathrm{~cm}$ away from the plates), three were installed at $1 \mathrm{~cm}$ depth and three at $10 \mathrm{~cm}$ depth, and an average temperature was used for each soil depth. A thermocouple was also installed in the tree canopy at $1 \mathrm{~m}$ above ground to monitor within canopy air temperature.

A datalogger (model CR23X, Campbell Scientific, Inc., Logan, UT) was used to record sensor measurements at $1 \mathrm{~Hz}$ then averaged to 5-min readings in 2008 and 15-min average readings in 2009 and 2010. Sensor readings were monitored daily to weekly for quality control and repair for possible sensor malfunction. At the beginning of each season, all sensors and their installation were rechecked for accuracy in readings and physical installation.

\subsection{Evapotranspiration and Crop Coefficient Calculations}

Based on the net radiation $\left(R_{n}\right)$, soil heat flux $(G)$, and air temperature $\left(T_{a}\right)$ and relative humidity $\left(h_{r}\right)$ measurements, latent energy (LE or $\lambda E$ ) available for evapotranspiration in the peach orchard was estimated using the Bowen ratio method:

$$
\lambda E=\frac{R_{n}-G}{1+B R}
$$

where BR is the Bowen ratio which was computed from:

$$
B R=\gamma \frac{T_{a}^{l}-T_{a}^{u}}{e_{a}^{l}-e_{a}^{u}}
$$

\footnotetext{
${ }^{1}$ Mention of trade names or commercial products in this publication is solely for the purpose of providing specific information and does not imply recommendation or endorsement by the U.S. Department of Agriculture.
} 
where $\gamma$ is apparent psychrometer constant $\left(0.0662 \mathrm{kPa}{ }^{\circ} \mathrm{C}^{-1}\right.$, Monteith and Unsworth, 1990); $T_{a}^{l}, T_{a}^{u}, e_{a}^{l}$ and $e_{a}^{u}$ are respectively air temperature and apparent vapor pressure measured at lower and upper beams above the canopy. As recommended by Foken et al. (1997) for ensuring sufficient wind turbulence, instantaneous BR calculations for wind speed differences $<0.3 \mathrm{~m} \mathrm{~s}^{-1}$ were excluded from BR calculations. Also the latent heat calculation would be undefined when $\mathrm{BR}=-1$, therefore all $\mathrm{BR}$ values between -0.75 and -1.25 were also excluded, as suggested by Ohmura (1982). To fill the gaps from excluded BR values, 30-min moving-windows averages were applied and used for latent heat calculations.

The vapor pressure ( $e_{a}^{l}$ and $e_{a}^{u}$ ) was calculated from relatively humidity and air temperature using the Tetens formula (Buck, 1981):

$$
e_{a}^{l, u}=h_{r}^{l, u}\left[a \exp \left(\frac{b T_{a}^{l, u}}{T_{a}^{l, u}+c}\right)\right]
$$

where coefficients used in the saturation vapor pressure function were $a=0.611 \mathrm{kPa}, b=$ 17.502, and $c=240.97{ }^{\circ} \mathrm{C}$ (Campbell and Norman, 1998). Bowen ratio method $\mathrm{ET}_{\mathrm{c}}$ was calculated by converting latent heat to depth of water.

To estimate peach water use from the FAO crop coefficient method, potential ET or $\mathrm{ET}_{\mathrm{o}}$ was calculated using the modified Penman-Monteith equation (Campbell and Norman, 1998):

$$
E T_{o}=\frac{s\left(R_{n}-G\right)+\gamma \lambda \mathrm{g}_{\mathrm{v}} D_{\mathrm{v}} / p_{a}}{s+\gamma}
$$

where parameter $s$ is slope of the saturation model fraction at apparent atmospheric pressure $\left(p_{a}\right), \lambda$ is latent heat of vaporization of water $\left(44 \mathrm{~kJ} \mathrm{~mol}^{-1}\right), g_{v}$ is total vapor conductance of the canopy, and $D_{v}$ is vapor pressure deficit. Parameters $s$ and $D_{v}$ were determined using measurements of $T_{a}$ and $h_{r}$ and the Tetens formula for saturation vapor pressure:

$$
\begin{aligned}
& s=\frac{a b c}{p_{a}\left(c+T_{a}\right)^{2}} \exp \left(\frac{b T_{a}}{c+T_{a}}\right) \\
& D_{v}=a\left(1-h_{r}\right) \exp \left(\frac{b T_{a}}{c+T_{a}}\right)
\end{aligned}
$$

where $T_{a}$ and $h_{r}$ from the upper beam were used in the calculations, and parameters a, b, c were the same as in equation (3).

Total vapor conductance of the canopy $\left(g_{v}\right)$ was computed from stomatal conductance $\left(g_{s}\right)$ 


\section{Macrothink}

and boundary layer aerodynamic conductance $\left(g_{a}\right)$ using the following:

$$
g_{v}=\frac{1}{\frac{1}{g_{s}}+\frac{1}{g_{a}}}
$$

where $g_{s}$ was assumed constant at $300 \mathrm{mmol} \mathrm{m} \mathrm{m}^{-2} \mathrm{~s}^{-1}$ for non-water stressed peach trees (Correia et al., 1997). The aerodynamic conductance depends on meteorological and boundary layer properties including wind speed and temperature gradient at the crop surface. The average June-August wind speed from 2008-2010 was $0.95 \mathrm{~m} \mathrm{~s}^{-1}$ (Table 1) and average difference between the canopy temperature and air temperature was $-2{ }^{\circ} \mathrm{C}$ (Wang and Gartung, 2010). This produced an average $g_{a}$ value of $250 \mathrm{mmol} \mathrm{m}^{-2} \mathrm{~s}^{-1}$ (Campbell and Norman, 1998). Thus an estimated average $g_{v}$ of $136 \mathrm{mmol} \mathrm{m}^{-2} \mathrm{~s}^{-1}$ was used for $\mathrm{ET}_{\mathrm{o}}$ calculations for the three year field experiment.

For energy partition assessment, the sensible heat $(H)$ component was also estimated using the Bowen ratio equation (Foken, 2008):

$$
H=\left(R_{n}-G\right) \frac{B R}{1+B R}
$$

Because a portion of the orchard was under post-harvest deficit irrigation, the composite effect would be reductions in $\mathrm{ET}_{\mathrm{c}}$ from full irrigation ET. This effect could be reflected as a stressed $\mathrm{K}_{\mathrm{c}}$ or a deficit $\mathrm{K}_{\mathrm{c}}$, and it was calculated as Bowen ratio $\mathrm{ET}_{\mathrm{c}}$ divided by $\mathrm{ET}_{\mathrm{o}}$.

\section{Results and Discussion}

\subsection{Meteorological Conditions during the Experiment}

For the postharvest months of June to August of 2009, as an example, daily air temperature in the peach orchard was found in the range of 10 to $15{ }^{\circ} \mathrm{C}$ for daily minimum to approximately 30 to $40{ }^{\circ} \mathrm{C}$ for daily maximum (Figure 2). From late June to end of August, air temperature inside the canopy at $1 \mathrm{~m}$ above ground was consistently lower than temperature at canopy top or $2 \mathrm{~m}$ above the canopy. Daily maximum at $2 \mathrm{~m}$ above the canopy was 1-2 degrees higher than temperature at the canopy top. The same trend was observed in 2008 and 2010, and as expected the monthly average air temperature was consistently the highest at $2 \mathrm{~m}$ above the canopy and the lowest at $1 \mathrm{~m}$ above ground inside the canopy (Table 1). Also air temperatures in June and August of 2008 were generally higher than temperatures observed in respective months in 2009 and 2010. 


\section{Macrothink}
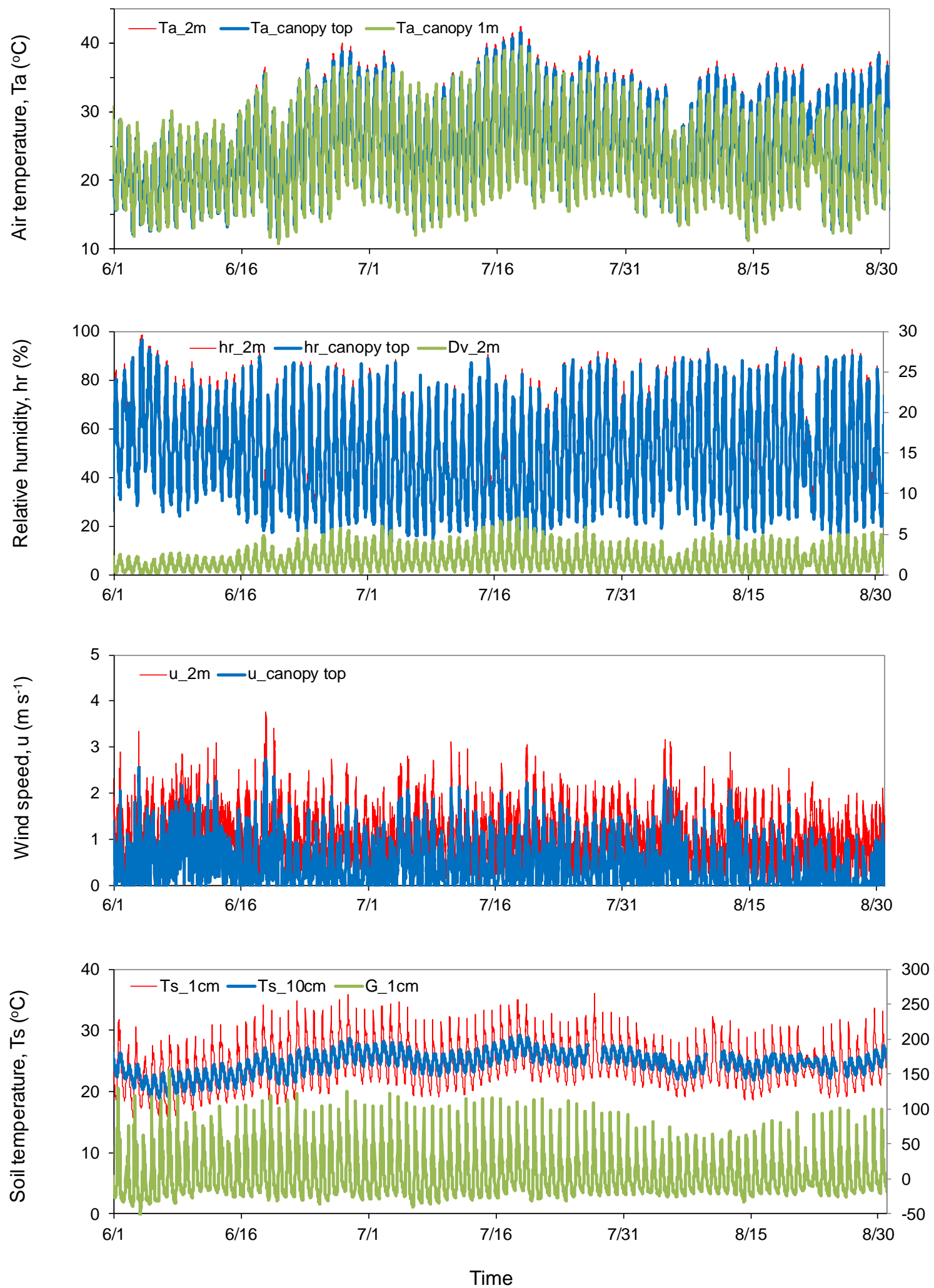

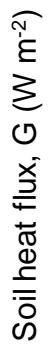

Figure 2. Real time meteorological variables measured in 2009 at the tower site in a peach orchard,

Parlier, CA 


\section{Ml Macrothink}

Table 1. Monthly average meteorological variables measured from 2008 to 2010 during postharvest deficit irrigation treatment in a peach orchard, Parlier, CA

\begin{tabular}{|c|c|c|c|c|}
\hline Month & Parameter $\dagger$ & 2008 & 2009 & 2010 \\
\hline \multirow[t]{11}{*}{ June } & $\mathrm{T}_{\mathrm{a}}\left({ }^{\circ} \mathrm{C}\right), 2 \mathrm{~m}$ above canopy & 24.8 & 23.3 & 23.9 \\
\hline & $\mathrm{T}_{\mathrm{a}}\left({ }^{\circ} \mathrm{C}\right)$, at canopy top & 24.0 & 22.9 & 23.6 \\
\hline & $\mathrm{T}_{\mathrm{a}}\left({ }^{\circ} \mathrm{C}\right), 1 \mathrm{~m}$ above ground & 23.3 & 22.3 & 23.1 \\
\hline & $\mathrm{h}_{\mathrm{r}}(\%), 2 \mathrm{~m}$ above canopy & 44.7 & 55.0 & 50.5 \\
\hline & $\mathrm{h}_{\mathrm{r}}(\%)$, at canopy top & 45.6 & 51.7 & 45.7 \\
\hline & $\mathrm{D}_{\mathrm{v}}(\mathrm{kPa}), 2 \mathrm{~m}$ above canopy & 2.07 & 1.55 & 1.71 \\
\hline & $\mathrm{u}\left(\mathrm{m} \mathrm{s}^{-1}\right), 2 \mathrm{~m}$ above canopy & 1.30 & 1.31 & 1.70 \\
\hline & $\mathrm{u}\left(\mathrm{m} \mathrm{s}^{-1}\right)$, at canopy top & 0.71 & 0.58 & 1.32 \\
\hline & $\mathrm{T}_{\mathrm{s}}\left({ }^{\circ} \mathrm{C}\right), 1 \mathrm{~cm}$ depth & 24.9 & 23.5 & 24.6 \\
\hline & $\mathrm{T}_{\mathrm{s}}\left({ }^{\circ} \mathrm{C}\right), 10 \mathrm{~cm}$ depth & 24.5 & 23.4 & 24.1 \\
\hline & $\mathrm{G}\left(\mathrm{W} \mathrm{m} \mathrm{m}^{-2}\right), 1 \mathrm{~cm}$ depth & 8.93 & 5.49 & 6.75 \\
\hline \multirow[t]{11}{*}{ July } & $\mathrm{T}_{\mathrm{a}}\left({ }^{\circ} \mathrm{C}\right), 2 \mathrm{~m}$ above canopy & 27.3 & 27.7 & 26.9 \\
\hline & $\mathrm{T}_{\mathrm{a}}\left({ }^{\circ} \mathrm{C}\right)$, at canopy top & 26.5 & 27.0 & 26.5 \\
\hline & $\mathrm{T}_{\mathrm{a}}\left({ }^{\circ} \mathrm{C}\right), 1 \mathrm{~m}$ above ground & 25.4 & 25.4 & $\mathrm{NA}+$ \\
\hline & $\mathrm{h}_{\mathrm{r}}(\%), 2 \mathrm{~m}$ above canopy & 52.0 & 48.2 & 54.8 \\
\hline & $\mathrm{h}_{\mathrm{r}}(\%)$, at canopy top & 51.3 & 45.6 & 49.7 \\
\hline & $\mathrm{D}_{\mathrm{v}}(\mathrm{kPa}), 2 \mathrm{~m}$ above canopy & 2.03 & 2.29 & 1.89 \\
\hline & $\mathrm{u}\left(\mathrm{m} \mathrm{s}^{-1}\right), 2 \mathrm{~m}$ above canopy & 1.20 & 1.23 & 1.25 \\
\hline & $\mathrm{u}\left(\mathrm{m} \mathrm{s}^{-1}\right)$, at canopy top & 0.62 & 0.47 & 0.73 \\
\hline & $\mathrm{T}_{\mathrm{s}}\left({ }^{\circ} \mathrm{C}\right), 1 \mathrm{~cm}$ depth & 27.7 & 25.6 & 26.9 \\
\hline & $\mathrm{T}_{\mathrm{s}}\left({ }^{\circ} \mathrm{C}\right), 10 \mathrm{~cm}$ depth & 26.3 & 25.9 & 27.8 \\
\hline & $\mathrm{G}\left(\mathrm{W} \mathrm{m} \mathrm{m}^{-2}\right), 1 \mathrm{~cm}$ depth & 4.88 & 3.78 & 4.24 \\
\hline \multirow[t]{11}{*}{ August } & $\mathrm{T}_{\mathrm{a}}\left({ }^{\circ} \mathrm{C}\right), 2 \mathrm{~m}$ above canopy & 27.0 & 25.7 & 24.8 \\
\hline & $\mathrm{T}_{\mathrm{a}}\left({ }^{\circ} \mathrm{C}\right)$, at canopy top & 26.3 & 25.0 & 24.3 \\
\hline & $\mathrm{T}_{\mathrm{a}}\left({ }^{\circ} \mathrm{C}\right), 1 \mathrm{~m}$ above ground & 24.5 & 22.8 & 21.6 \\
\hline & $\mathrm{h}_{\mathrm{r}}(\%), 2 \mathrm{~m}$ above canopy & 50.4 & 53.7 & 56.9 \\
\hline & $\mathrm{h}_{\mathrm{r}}(\%)$, at canopy top & 49.8 & 51.4 & 52.2 \\
\hline & $\mathrm{D}_{\mathrm{v}}(\mathrm{kPa}), 2 \mathrm{~m}$ above canopy & 2.10 & 1.85 & 1.68 \\
\hline & $\mathrm{u}\left(\mathrm{m} \mathrm{s}^{-1}\right), 2 \mathrm{~m}$ above canopy & 1.07 & 1.10 & 1.16 \\
\hline & $\mathrm{u}\left(\mathrm{m} \mathrm{s}^{-1}\right)$, at canopy top & 0.46 & 0.32 & 0.60 \\
\hline & $\mathrm{T}_{\mathrm{s}}\left({ }^{\circ} \mathrm{C}\right), 1 \mathrm{~cm}$ depth & 25.9 & 24.0 & 23.2 \\
\hline & $\mathrm{T}_{\mathrm{s}}\left({ }^{\circ} \mathrm{C}\right), 10 \mathrm{~cm}$ depth & 25.1 & 24.6 & 24.9 \\
\hline & $\mathrm{G}\left(\mathrm{W} \mathrm{m}^{-2}\right), 1 \mathrm{~cm}$ depth & 2.75 & 2.60 & 3.96 \\
\hline
\end{tabular}

$\dagger \mathrm{T}_{\mathrm{a}}=$ air temperature, $\mathrm{h}_{\mathrm{r}}=$ relative humidity, $\mathrm{D}_{\mathrm{v}}=$ vapor pressure deficit, $\mathrm{u}=$ wind speed, $\mathrm{T}_{\mathrm{s}}$ $=$ soil temperature, $\mathrm{G}=$ soil heat flux; $\$ \mathrm{NA}=$ data not available. 
Responding to diurnal temperature fluctuations and vapor density changes, for the months of June to August 2009 relative humidity ranged from approximately $20-30 \%$ for daily lows to $80-90 \%$ for daily highs (Figure 2). Monthly averages ranged from 45 to $55 \%$ for the three year period during the study (Table 1). For potential evapotranspiration calculations, vapor pressure deficit was computed at $2 \mathrm{~m}$ above the canopy and the values in 2009 generally ranged from 0 to $5 \mathrm{kPa}$ (Figure 2). Monthly averages of vapor pressure deficit were from 1.6 to $2.3 \mathrm{kPa}$ during the three year experiment (Table 1). Similar to air temperature observations, relatively higher vapor pressure deficit values were found for June and August of 2008 than that in respective months of 2009 and 2010 (Table 1).

Measured wind speed during the three month period was relatively low where the daily maximum was generally less than $3 \mathrm{~m} \mathrm{~s}^{-1}$ (Figure 2). As expected, wind speed at $2 \mathrm{~m}$ above the canopy was consistently higher than that at the canopy level and the monthly average wind speed from June to August of 2008 to 2010 was $1.1-1.7 \mathrm{~m} \mathrm{~s}^{-1}$ at $2 \mathrm{~m}$ above the canopy and $0.3-1.3 \mathrm{~m} \mathrm{~s}^{-1}$ at the canopy level (Table 2).

Soil temperature at $1 \mathrm{~cm}$ depth fluctuated diurnally from upper teens to low $30{ }^{\circ} \mathrm{C}$ whereas temperature at $10 \mathrm{~cm}$ depth was at low to mid $20^{\circ} \mathrm{C}$ (Figure 2). Monthly average temperature ranged from 23 to $28{ }^{\circ} \mathrm{C}$ for the three year experiment (Table 1). Higher soil temperature was found in the month of July $\left(26-28{ }^{\circ} \mathrm{C}\right)$ than in June or August $\left(23-26^{\circ} \mathrm{C}\right)$. Soil heat flux also showed strong diurnal variations reaching a daily maximum of approximately $125 \mathrm{~W} \mathrm{~m}^{-2}$ (Figure 2). As expected, the monthly average heat flux decreased from 5.5-8.9 $\mathrm{W} \mathrm{m}^{-2}$ in June to $3.8-4.9 \mathrm{~W} \mathrm{~m}^{-2}$ in July to $2.6-4.0 \mathrm{~W} \mathrm{~m}^{-2}$ in August (Table 1).

Although 2008 appeared to be a warmer year than 2009 and 2010, in general, these meteorological parameters found during the three year period were within the limit of long term averages for the area (CIMIS, 2013).

\subsection{Bowen Ratio Data Quality Control and Energy Partition}

Figure 3 shows the 30-min moving windows averages of 5-min cumulative $\mathrm{ET}_{\mathrm{c}}$ in 2008, as an example, for before (a) and after (b) data quality control by excluding conditions when wind speed difference $<0.3 \mathrm{~m} \mathrm{~s}^{-1}$ (Foken et al., 1997) or $-1.25<\beta<-0.75$ (Ohmura, 1982). Clearly, the data quality control procedures removed the unreasonably artificial high $\mathrm{ET}_{\mathrm{c}}$ values caused by the inherent limitations of the Bowen ratio method. The same data quality control procedure was applied to the entire dataset from the three year field study. The basis of the Bowen ratio method assumes that the ratio of the gradients of temperature and humidity between two heights behaves similarly to the ratio of the sensible to the latent heat flux (Dugas et al., 1991). However, both the sensible and latent heat flux do not explicitly consider wind speed differences at the two heights or differences between the measurement heights. Larger differences between the measurement heights would most likely increase the differences in measured air temperature and humidity, hence making the Bowen ratio method more robust. Local or regional meteorological characteristics can also add needed requirements for deployment of the Bowen ratio method. Places with more frequent low wind speed or mixing conditions for turbulence likely require larger height separation than areas 

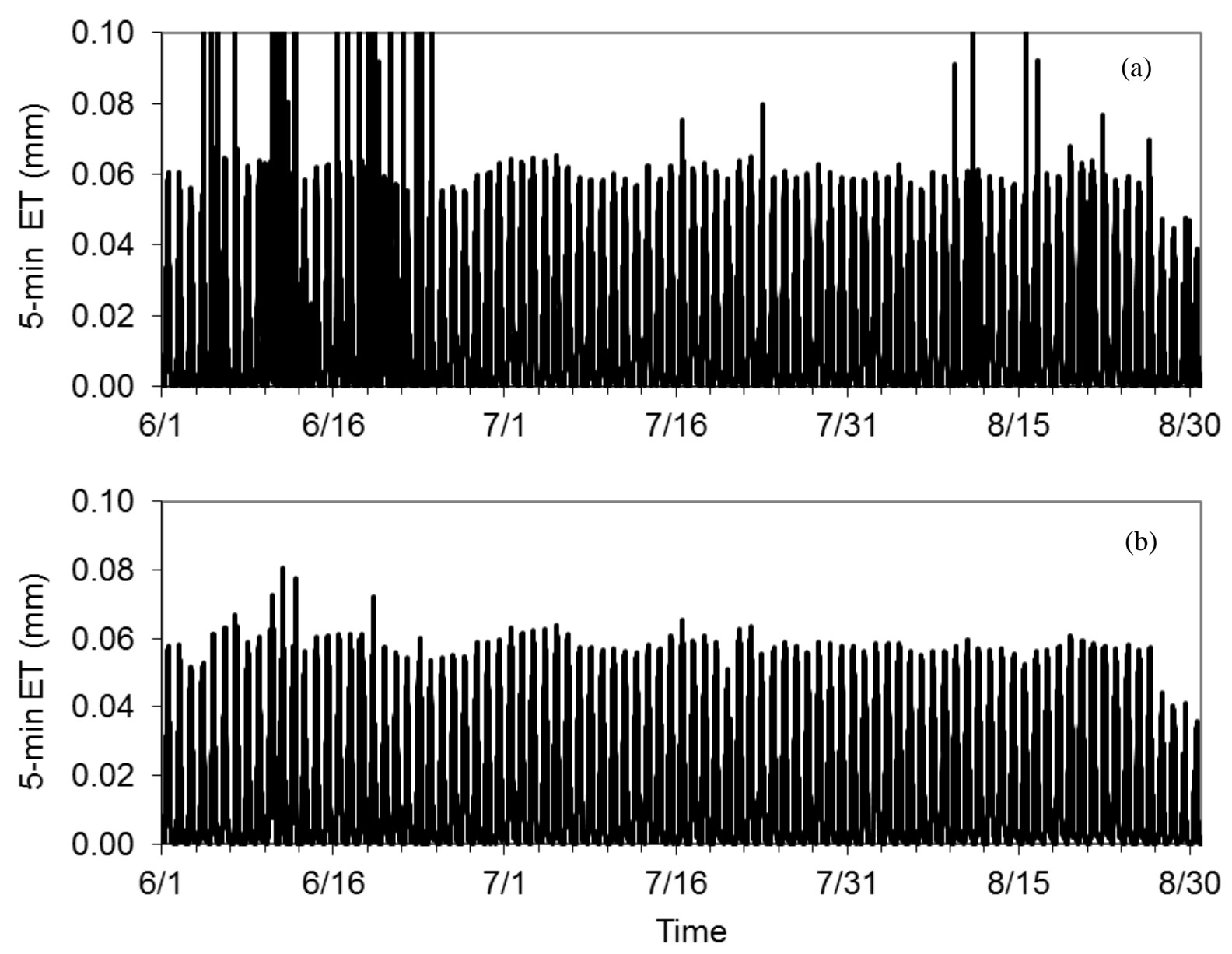

Figure 3. Real time 2008 crop evapotranspiration or ET before (a) and after (b) data quality control by excluding conditions when wind speed difference $<0.3 \mathrm{~m} \mathrm{~s}^{-1}$ (Foken et al., 1997) or $-1.25<\quad<-0.75$ (Ohmura, 1982) and taking 30-min moving windows averages of 5-min cumulative ET measurements

frequently see strong wind turbulence. Logistic considerations, however, often limit the height separation, especially for perennial tall plants such as trees and vines in that the lower measurement height also needs to be at or above the canopy top. Teixeira et al. (2008) used 3-m height above a mango tree canopy for the upper beam measurement of a Bowen ratio system and Heilman et al. (1994) placed the sensors at 1-m above a vineyard canopy. The 2-m height separation used in this study was a compromise between accuracy and logistical feasibility. With this height and the $138 \mathrm{~m}$ distance upwind to the field edge, the fetch-to-height ratio would be 69:1 which was well above the minimum requirement for Bowen ratio measurements.

To illustrate energy partition, one day from July to August or the peak evaporative periods was randomly selected for each of the three years of field measurements (Figure 4). As shown in the figure, $75-85 \%$ of the daily Rn was used by latent heat (LE), $25-13 \%$ by sensible heat, 


\section{Macrothink}
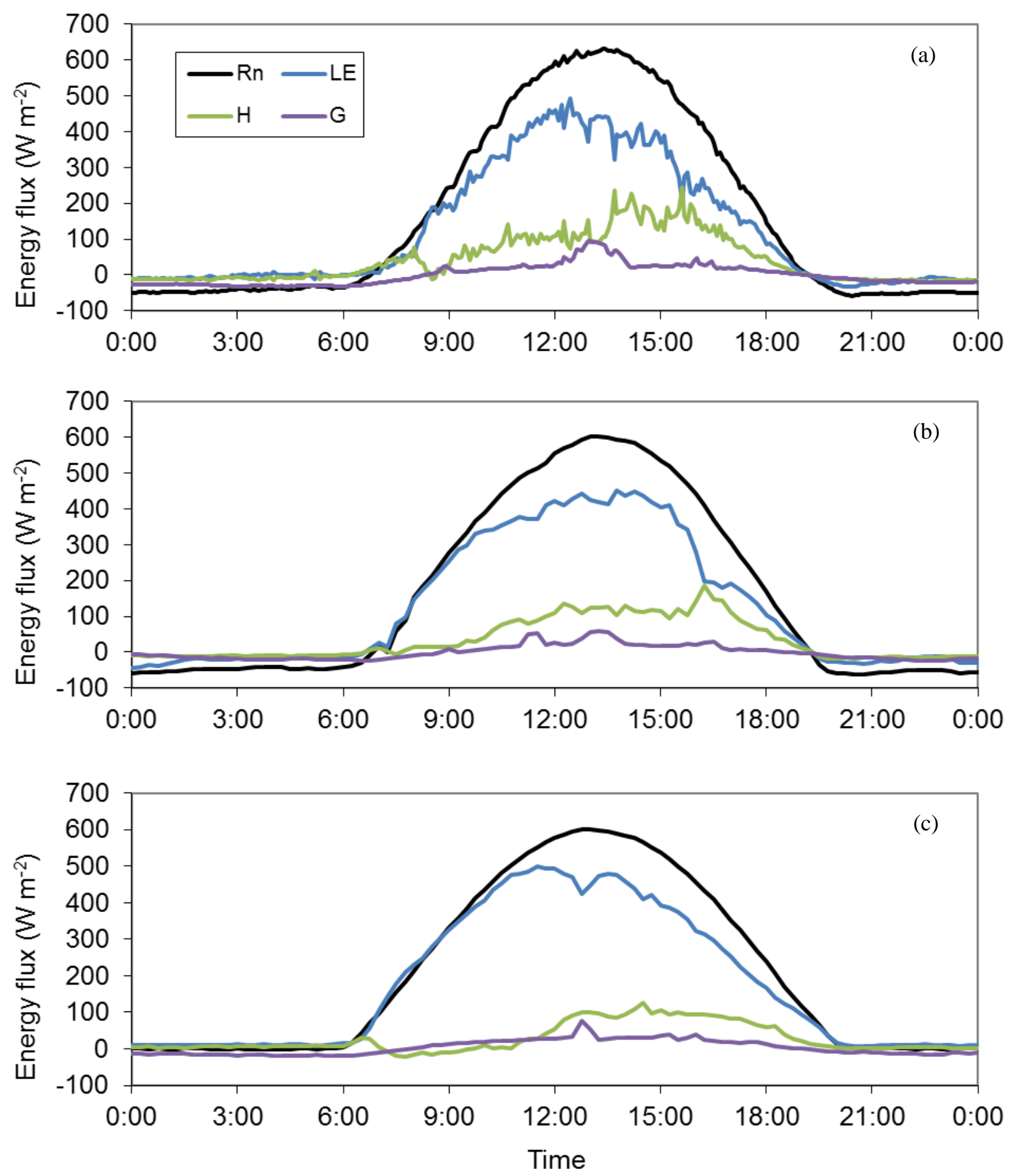

Figure 4. Diurnal energy fluxes of net radiation Rn, latent heat LE, sensible heat $\mathrm{H}$, and soil heat G for (a) 29 July 2008, (b) 14 August 2009, and (c) 19 July 2010

and nearly a net zero usage for soil heat flux. Similar energy partitions were observed in a mature mango orchard ( $\mathrm{LE}=80-85 \% \mathrm{Rn}$; Teixeira et al., 2008), in a young olive orchard (approximately 70\%; Testi et al., 2004), and in both wine and table grape vineyards (88\%; Teixeira et al., 2007). The relatively low sensible heat was unique to the area where surface boundary layer is often under stable conditions with light winds especially in the mornings 
(Castellvi and Snyder, 2009; CIMIS, 2013). Convective conditions tend to start in the afternoon after receiving solar heating in the morning. The dominant wind pattern will be different if experiencing an incoming storm system but it is rare for the area during the summer growing months. The small net soil heat flux was attributed to low exposure of bare soil. Independent canopy cover measurements with a TetraCam camera showed approximately $90 \%$ ground canopy cover during the months of June - August in this orchard.

\subsection{Comparison of Crop Coefficients and Evapotranspiration}

Actual crop coefficients $\left(\mathrm{K}_{\mathrm{c}}\right)$ under postharvest deficit irrigation, thereafter termed Deficit_ $\mathrm{K}_{\mathrm{c}}$, were computed as ratios of $\mathrm{ET}_{\mathrm{c}}$ estimated from the Bowen ratio method over $\mathrm{ET}_{\mathrm{o}}$ (Figure 5). For comparison purposes, the time-dependent linear relationship developed for the same peach variety from a field site under fully irrigated conditions and in close proximity to this study site (Johnson et al., 2005) was used to calculate the "potential" crop coefficients, thereafter termed Lysimeter_ $\mathrm{K}_{\mathrm{c}}$. It is worth to note that the Lysimeter_K $\mathrm{K}_{\mathrm{c}}$ increased linearly until day of year (DOY) 187 or July 6 then remained constant at 1.20. As shown in the figures, Deficit_K $K_{c}$ values were consistently lower than Lysimeter_ $K_{c}$ in 2008 starting in early June. In 2009 and 2010, Deficit_K $K_{c}$ values were similar to Lysimeter_ $K_{c}$ until July when it became slightly lower than Lysimeter_ $\mathrm{K}_{\mathrm{c}}$. Discrepancies in Deficit_ $\mathrm{K}_{\mathrm{c}}$ and Lysimeter_ $\mathrm{K}_{\mathrm{c}}$ between 2008 and the following two years were likely attributed to the higher temperatures occurred in 2008 than in 2009 or 2010 . The generally lower values of Deficit_ $K_{c}$ in all three years, compared to the Lysimeter_ $\mathrm{K}_{\mathrm{c}}$ values, were attributed to the deficit irrigation treatments in the orchard. The average reduced (from 1.20) maximum crop coefficient, by the deficit irrigation treatments, was $0.90,1.03$, and 1.07 for 2008, 2009, and 2010, respectively. Rather than DOY 187, as in the full irrigation lysimeter study, the time for reaching the maximum Deficit_K $K_{c}$ was DOY 158 in 2008 (06/08/2008), DOY 168 in 2009 (06/17/2009), and DOY 172 in 2010 (06/21/2010), respectively. These findings indicated that after the onset of deficit irrigation treatment in early June, overall crop water use started to decrease and reached a "stressed" equilibrium maximum value sooner than the typical DOY 187 date and at values lower than 1.20 should all the trees be fully irrigated. Also, only $17 \%$ of the orchard was deficit irrigated. Should the entire orchard be managed under deficit irrigation, smaller Deficit_K $\mathrm{K}_{\mathrm{c}}$ values would be expected.

As shown in Figure 6, comparisons were made in estimated $\mathrm{ET}_{\mathrm{c}}$ using Lysimeter_ $\mathrm{K}_{\mathrm{c}}$, Deficit_ $\mathrm{K}_{\mathrm{c}}$, and Bowen ratio values for each year. As expected, the $\mathrm{ET}_{\mathrm{c}}$ values estimated from Lysimeter_ $\mathrm{K}_{\mathrm{c}}$ was higher or overly estimated than that using the Deficit $\mathrm{K}_{\mathrm{c}}$ for most of the postharvest periods: early June to end of August in 2008, late June to end of August in 2009, and July to August in 2010. $\mathrm{ET}_{\mathrm{c}}$ values determined using the Deficit_ $\mathrm{K}_{\mathrm{c}}$ were virtually the same as the direct Bowen ratio estimates. It is important to note the interdependence of determination of Deficit_ $\mathrm{K}_{\mathrm{c}}$ on Bowen ratio estimates of $\mathrm{ET}_{\mathrm{c}}$. The merit with using a deficit 

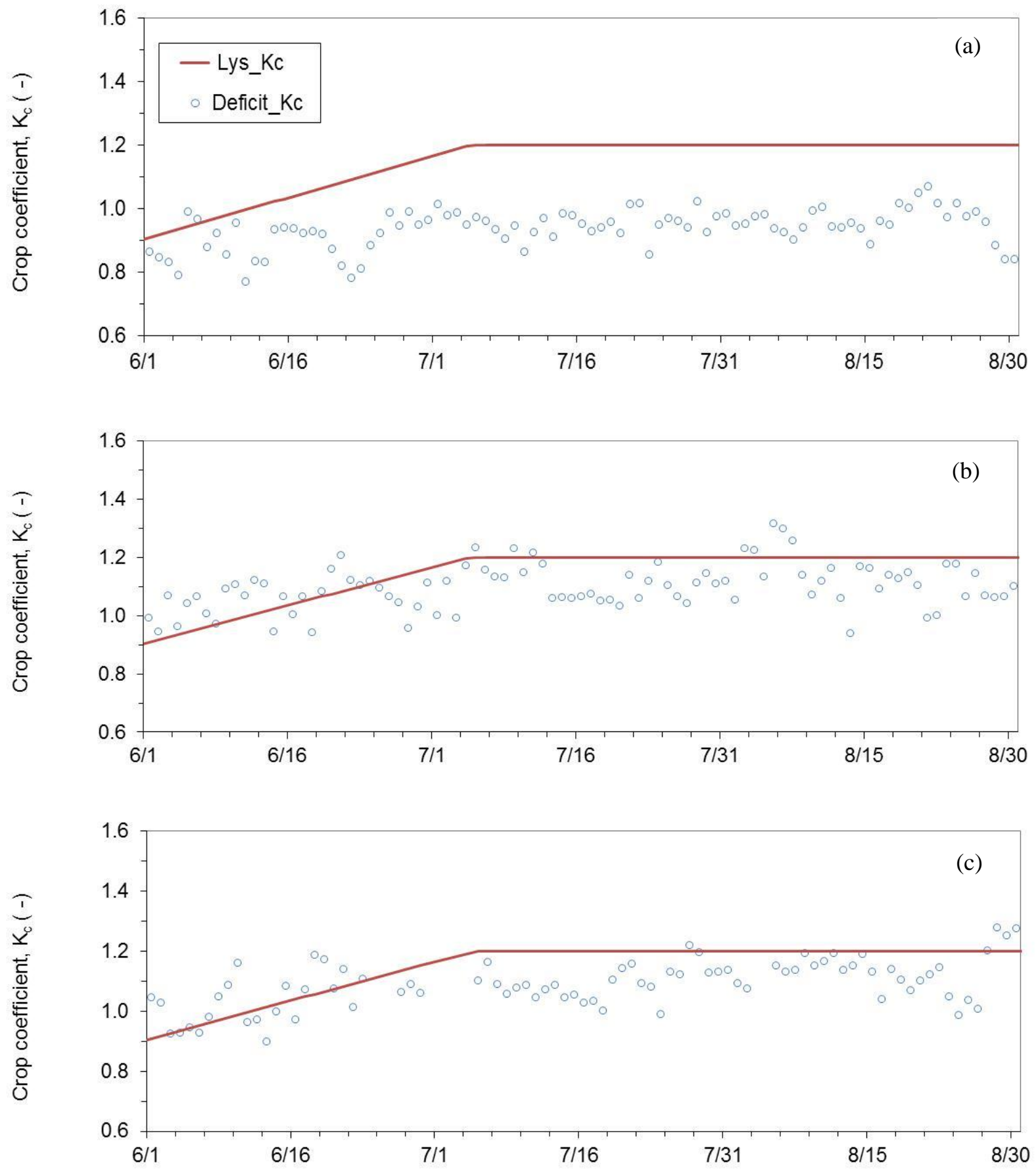

Time

Figure 5. Daily crop coefficients of peach orchard under postharvest deficit irrigation in (a) 2008, (b) 2009, and (c) 2010. Lysimeter_Kc or Lys_Kc = crop coefficient from lysimeter measurement under full irrigation (Johnson et al., 2005). Deficit_Kc $=$ crop coefficient computed from potential ET (ETo) and actual ET (ETc) from Bowen ratio measurement 

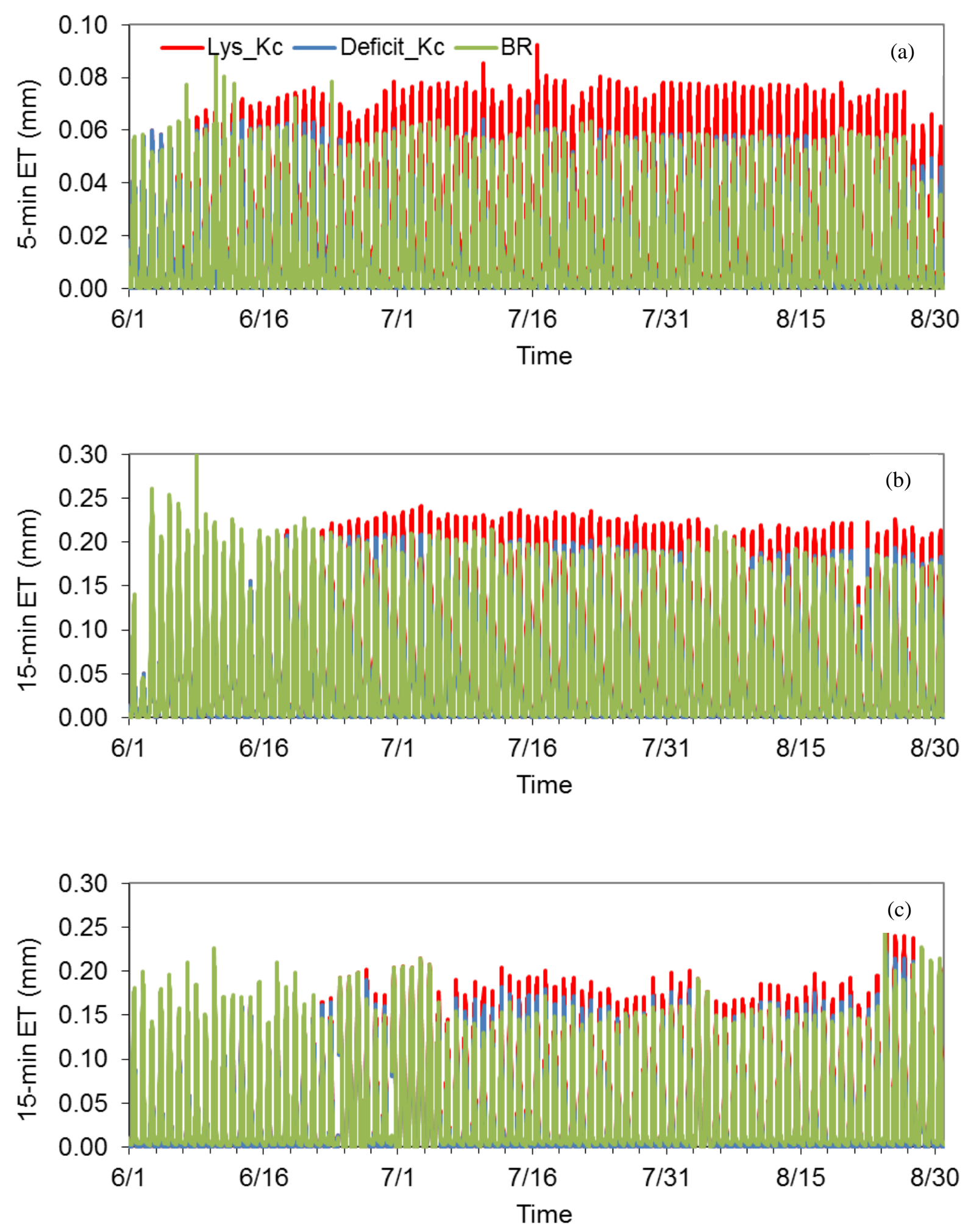

Figure 6. Comparison of real time $\mathrm{ET}_{\mathrm{c}}$ using the Lysimeter_ $\mathrm{K}_{\mathrm{c}}$, Deficit_ $\mathrm{K}_{\mathrm{c}}$, and the Bowen ratio (BR) methods for (a) 2008, (b) 2009, and (c) 2010 
$\mathrm{K}_{\mathrm{c}}$ is the simple analogy to the FAO 56 method of using $\mathrm{K}_{\mathrm{c}}$ to manage irrigation scheduling, should a known or predetermined deficit is given. To further illustrate the improvement of Deficit_K $\mathrm{K}_{\mathrm{c}}$ on $\mathrm{ET}_{\mathrm{c}}$ assessment, diurnal 5-min or 15-min $\mathrm{ET}_{\mathrm{c}}$ values were compared for the dates when $K_{c}$ reached the maximum $K_{c}$ (i.e., 06/08/2008, 06/17/2009, 06/21/2010) with that of July 31 of respective years (Figure 7). As can be seen in the figures, the three methods of $\mathrm{ET}_{\mathrm{c}}$ estimates were similar up to reaching the respective maximum deficit $\mathrm{K}_{\mathrm{c}}$ values. $\mathrm{ET}_{\mathrm{c}}$ values on July 31 clearly showed over-prediction using the lysimeter $\mathrm{K}_{\mathrm{c}}$, especially during middle part of the day. This is virtually caused the larger value for the multiplier (i.e. 1.20) than the reduced maximum Deficit $\mathrm{K}_{\mathrm{c}}$ (i.e., 0.90, 1.03, and 1.07 for 2008, 2009, and 2010 respectively). Using the lysimeter $\mathrm{K}_{\mathrm{c}}$ values up to reaching the maximum Deficit $\mathrm{K}_{\mathrm{c}}$, then using the constant Deficit $\mathrm{K}_{\mathrm{c}}$, monthly cumulative ET $_{\mathrm{c}}$ was calculated and compared with cumulative $\mathrm{ET}_{\mathrm{c}}$ estimated using the lysimeter_ $\mathrm{K}_{\mathrm{c}}$ and Bowen ratio methods for the three years (Table 2). Cumulative $\mathrm{ET}_{\mathrm{c}}$ in June showed variable differences between the three methods because the onset of deficit irrigation likely had different initial impact on crop water use. In July and August, the Lysimeter $\mathrm{K}_{\mathrm{c}}$ method consistently over-predicted cumulative $\mathrm{ET}_{\mathrm{c}}$ compared to the Deficit_ $\mathrm{K}_{\mathrm{c}}$ and the Bowen ratio methods. The results also indicated that if Deficit $\mathrm{K}_{\mathrm{c}}$ can be determined or pre-selected, then the well-established FAO 56 method for $\mathrm{ET}_{\mathrm{c}}$ (Allen et al., 1998) may be used for deficit irrigation management. The other way to describe water stress under deficit irrigation is to use a crop coefficient stress factor, e.g. $K_{s}$, as proposed in Allen (2000) and adopted in Suleiman et al. (2007) for deficit irrigation of cotton. For this study, the $\mathrm{K}_{\mathrm{s}}$ factor would be the ratio of maximum deficit $\mathrm{K}_{\mathrm{c}}$ over 1.20 or $0.75,0.86$, and 0.89 for 2008, 2009, and 2010, respectively. For times before reaching the maximum $\mathrm{K}_{\mathrm{c}}$, the $\mathrm{K}_{\mathrm{s}}$ factor would be one.

The reason for a reduced maximum $\mathrm{K}_{\mathrm{c}}$ in deficit irrigation management where crops are under some degree of water stress is generally believed to be caused by stomatal regulation or reduced stomatal conductance under these conditions. The challenge is how to estimate the degree of stress or deviation of $K_{c}$ from non-stressed conditions or basal $K_{c}\left(K_{c b}\right)$ values. Some recent approaches explored using thermal images from satellite (e.g., the METRIC model by Allen et al., 2007) or unmanned aerial vehicles (UAVs, e.g., Zarco-Tejada et al., 2012) to make water stress assessment. The merit with thermal images is the ability to detect spatial variations in canopy temperature to infer water status or water stress caused by soil variability or by variations in irrigation distribution uniformity. Under deficit irrigation, all plants are under some water stress and spatial variability can make certain areas in an orchard over-stressed to levels that might cause physiologically irreversible damages to the trees (Fereres and Soriano, 2007). Therefore, the selection of levels of irrigation deficit in terms of a deficit $\mathrm{K}_{\mathrm{c}}$ value or a similar benchmark irrigation level with respect to $\mathrm{ET}_{\mathrm{o}}$ should consider the potential spatial variability of water availability on a farm scale to minimize risks on crop losses. In other words, some safety factor should be used in choosing a deficit $\mathrm{K}_{\mathrm{c}}$ for deficit irrigation. This study, in an inverse way, clearly demonstrated that water stress under deficit irrigation treatment can be characterized in $\mathrm{K}_{\mathrm{c}}$ or so defined as Deficit_K $\mathrm{K}_{\mathrm{c}}$. If values of Deficit_ $\mathrm{K}_{\mathrm{c}}$ can be pre-determined, the approach may be used to provide guidance on deploying deficit irrigation practices. 

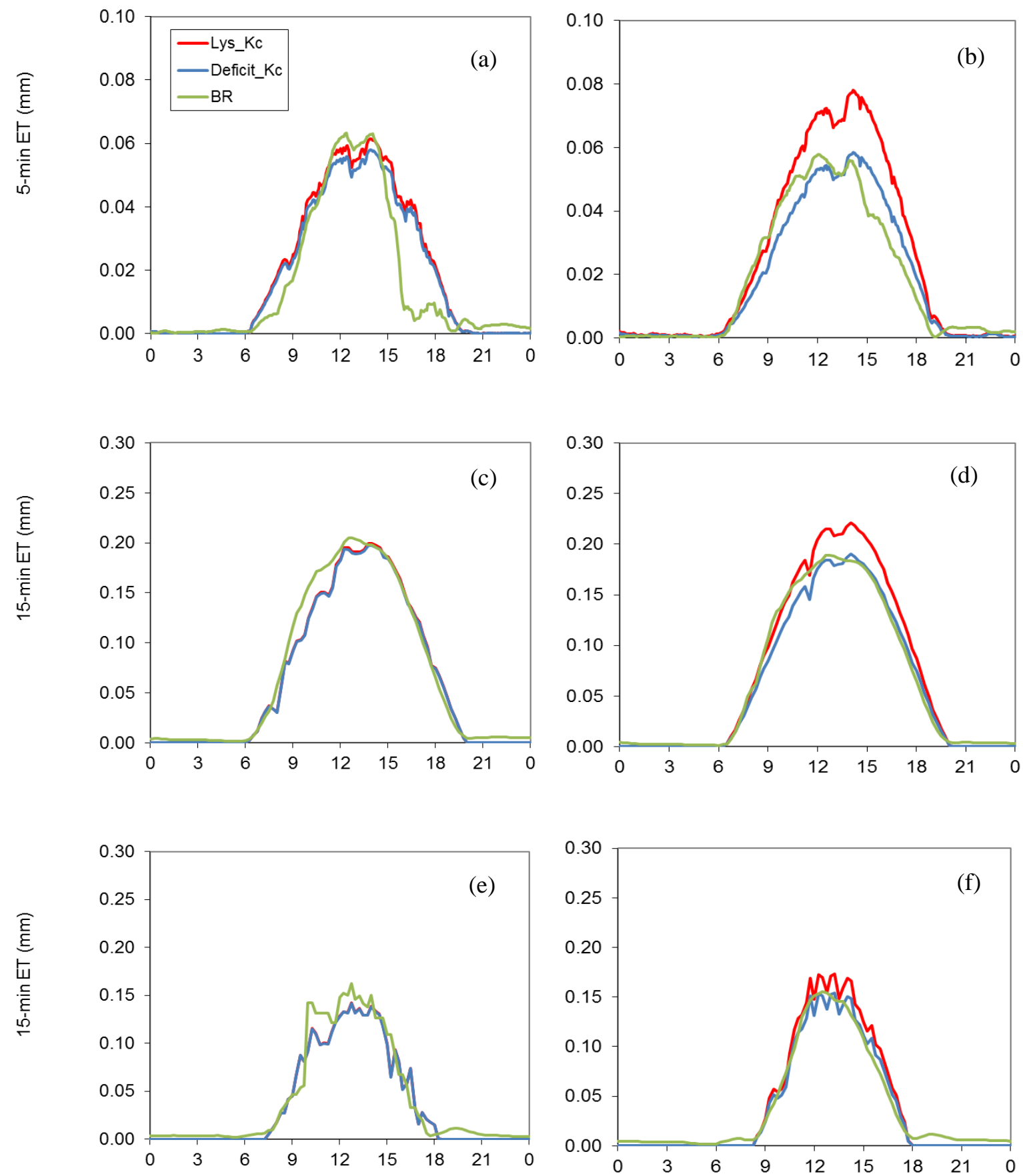

Hour of day

Hour of day

Figure 7. Comparison of real time ETc using lysimeter Kc, deficit Kc, and Bowen ratio (BR) measurement for (a) 8 June 2008, (b) 31 July 2008, (c) 17 June 2009, (d) 31 July 2009, (e) 21 June 2010, and (f) 31 July 2010 
Table 2. Monthly cumulative crop evapotranspiration $\left(\mathrm{ET}_{\mathrm{c}}\right)$ in 2008, 2009, and 2010 in a peach orchard received postharvest deficit irrigation in 12 randomly distributed plots from a total of 72 plots (Figure 1)

\begin{tabular}{lllll}
\hline \multirow{3}{*}{ Month } & Method $\dagger$ & Cumulative $\mathrm{ET}_{\mathrm{c}}(\mathrm{mm})$ & \\
\hline June & Lysimeter $\mathrm{K}_{\mathrm{c}}$ & 2008 & 2009 & 2010 \\
& Deficit $\mathrm{K}_{\mathrm{c}}$ & 177.7 & 165.8 & 113.2 \\
& Bowen ratio & 155.7 & 160.0 & 111.3 \\
\multirow{3}{*}{ July } & & 136.0 & 186.6 & 129.7 \\
& Lysimeter $\mathrm{K}_{\mathrm{c}}$ & & & \\
& ${\text { Deficit } \mathrm{K}_{\mathrm{c}}}^{\text {August }}$ & 216.2 & 228.2 & 140.3 \\
& Bowen ratio & 162.3 & 196.5 & 125.6 \\
& & 162.4 & 194.4 & 129.0 \\
& Lysimeter $\mathrm{K}_{\mathrm{c}}$ & & & \\
& Deficit $\mathrm{K}_{\mathrm{c}}$ & 201.7 & 197.2 & 142.0 \\
& Bowen ratio & 151.3 & 169.3 & 126.6 \\
\hline
\end{tabular}

$\dagger$ Lysimeter $\mathrm{K}_{\mathrm{c}}$ method was product of potential evapotranspiration $\left(\mathrm{ET}_{\mathrm{o}}\right)$ and lysimeter crop coefficient (Johnson et al., 2005). Deficit $\mathrm{K}_{\mathrm{c}}$ method was product of $\mathrm{ET}_{\mathrm{o}}$ and deficit $\mathrm{K}_{\mathrm{c}}$, i.e. correcting for deficit irrigation effect on maximum crop coefficient $K_{c} \leq 0.90(2008), \leq 1.03$ (2009), $\leq 1.07$ (2010). Bowen ratio method $\mathrm{ET}_{\mathrm{c}}$ was direct conversion of total monthly latent heat to water depth.

\section{References}

Allen, R. G. (2000). Using the FAO-56 dual crop coefficient method over an irrigated region as part of an evapotranspiration intercomparison study. Journal of Hydrology, 229, 27-41. http://dx.doi.org/10.1016/S0022-1694(99)00194-8

Allen, R. G., Pereira, L. S., Raes, D., \& Smith, M. (1998). Crop evapotranspiration. Guidelines for computing crop water requirements. FAO Irrigation and Drainage Paper No. 56, FAO, Rome, Italy.

Allen, R., Tasumi, M., \& Trezza, R. (2007). Satellite-based energy balance for mapping evapotranspiration with internalized calibration (METRIC) - Model. Journal of Irrigation and Drainage Engineering, 133, 380-394.

http://dx.doi.org/10.1061/(ASCE)0733-9437(2007)133:4(380)

Angus, D. E., \& Watts, P. J. (1984). Evapotranspiration - how good is the Bowen ratio method? Agricultural Water Management, 8, 133-150.

http://dx.doi.org/10.1016/0378-3774(84)90050-7

Baldocchi, D. D. (1988). Measuring biosphere-atmosphere exchanges of biologically related gases with micrometeorological methods. Ecology, 69, 1331-1340.

http://dx.doi.org/10.2307/1941631

Bryla, D. R., Dickson, E., Shenk, R., Johnson, R. S., Crisosto, C. H., \& Trout, T. J. (2005). Influence of irrigation method and scheduling on patterns of soil and tree water status and its 
relation to yield and fruit quality in peach. HortScience, 40, 2118-2124.

Buck, A. L. (1981). New equations for computing vapor pressure and enhancement factor. Journal of Applied Meteorology, 20, 1527-1532.

http://dx.doi.org/10.1175/1520-0450(1981)020<1527:NEFCVP>2.0.CO;2

CIMIS (2013). California Irrigation Management Information System, Department of Water Resources, State of California, Sacramento, CA.

ttp://wwwcimis.water.ca.gov/cimis/data.jsp

Campbell, G. S., \& Norman, J. M. (1998). An introduction to environmental biophysics. $2^{\text {nd }}$ Edition. Springer, New York, NY. http://dx.doi.org/10.1007/978-1-4612-1626-1

Castellvi, F., \& Snyder, R. L. (2009). Sensible heat flux estimates using surface renewal analysis- a study case over a peach orchard. Agricultural and Forest Meteorology, 149, 1397-1402. http://dx.doi.org/10.1016/j.agrformet.2009.03.011

Chalmers, D. J., Mitchell, P. D., \& van Heek, L. (1981). Control of peach tree growth and productivity by regulated water supply, tree density and summer pruning. Journal of American Society of Horticultural Science, 106, 307-312.

Correia, M. J., Rodrigues, M. L., Ferreira, M. I., \& Pereira, J. S. (1997). Diurnal change in the relationship between stomatal conductance and abscisic acid in the xylem sap of field-grown peach trees. Journal of Experimental Botany, 48, 1727-1736. http://dx.doi.org/10.1093/jxb/48.9.1727

Costa, J. M., Ortuno, M. F., \& Chaves, M. M. (2007). Deficit irrigation as a strategy to save water: physiology and potential application to horticulture. Journal of Integrative Plant Biology, 49, 1421-1434. http://dx.doi.org/10.1111/j.1672-9072.2007.00556.x

Doorenbos, J., \& Pruitt, W. O. (1977). Crop water requirement. FAO Irrigation and Drainage Paper, 24, FAO, Rome, Italy.

Dugas, W. A., Fritschen, L. J., Gay, L. W., Held, A. A., Matthias, A. D., Reicosky, D. C., Steduto, P., \& Steiner, J. L. (1991). Bowen ratio, eddy correlation, and portable chamber measurements of sensible and latent heat flux over irrigated spring wheat. Agricultural and Forest Meteorology, 56, 1-20. http://dx.doi.org/10.1016/0168-1923(91)90101-U

Dugas, W. A., Upchurch, D. R., \& Ritchie, J. T. (1985). A weighing lysimeter for evapotranspiration and root measurements. Agronomy Journal, 77, 821-825. http://dx.doi.org/10.2134/agronj1985.00021962007700050036x

Falagán, N., Artés, F., Gómez, P. A., Artés-Hernández, F., Conejero, W., \& Aguayo, E. (2015). Deficit irrigation strategies enhance health-promoting compounds through the intensification of specific enzymes in early peaches. Journal of the Science of Food and Agriculture. http://dx.doi.org/10.1002/jsfa.7290

Fereres, E., \& Soriano, M. A. (2007). Deficit irrigation for reducing agricultural water use. Journal of Experimental Botany, 58, 147-159. http://dx.doi.org/10.1093/jxb/erl165 
Foken, T. (2008). Micrometeorology. Springer, New York, NY.

Foken, T., Richter, S. H., \& Muller, H. (1997). Zur Genauigkeit der Bowen ratio method. Wetter und Leben, 49, 57-77.

Fuchs, M., \& Tanner, C. B. (1970). Error analysis of Bowen ratios measured by differential psychrometry. Agricultural Meteorology, 7, 329-334.

http://dx.doi.org/10.1016/0002-1571(70)90027-0

Girón, I. F., Corell, M., Martín-Palomo, M. J., Galindo, A., Torrecillas, A., Moreno, F., \& Moriana, A. (2015). Feasibility of trunk diameter fluctuations in the scheduling of regulated deficit irrigation for table olive trees without reference trees. Agricultural Water Management, 161, 114-126. http://dx.doi.org/10.1016/j.agwat.2015.07.014

Girona, J., Gelly, M., Matta, M., Arbones, A., Rufat, J., \& Marsal, J. (2005). Peach tree response to single and combined deficit irrigation regimes in deep soils. Agricultural Water Management, 72, 97-108. http://dx.doi.org/10.1016/j.agwat.2004.09.011

Goldhamer, D. A., Fereres, E., Mata, M., Girona, J., \& Cohen, M. (1999). Sensitivity of continuous and discrete plant and soil water status monitoring in peach trees subjected to deficit irrigation. Journal of American Society of Horticultural Sciences, 124, 437-444.

Heilman, J. L., McInnes, K. J., Savage, M. J., Gesch, R. W., \& Lascano, R. J. (1994). Soil and canopy energy balances in a west Texas vineyard. Agricultural and Forest Meteorology, 71, 99-114. http://dx.doi.org/10.1016/0168-1923(94)90102-3

Howell, T. A., McCormick, R. L., \& Phene, C. J. (1985). Design and installation of large weighing lysimeters. Transactions of American Society of Agricultural Engineers, 28, 106-117. http://dx.doi.org/10.13031/2013.32212

Johnson, S. R., Handley, D. F., \& DeJong, T. M. (1992). Long-term response of early maturing peach trees to postharvest water deficits. Journal of American Society of Horticultural Science, 117, 881-886.

Johnson, S. R., Williams, L. E., Ayars, J. E., \& Trout, T. J. (2005). Weighing lysimeters aid study of water relations in tree and vine crops. California Agriculture, 59, 133-136. http://dx.doi.org/10.3733/ca.v059n02p133

Klonsky, K. (2012). California agricultural profitable and growing. California Agriculture, 66, 78. http://dx.doi.org/10.3733/ca.v066n03p78

Monteith, J. L., \& Unsworth, M. (1990). Principles of environmental physics, $2^{\text {nd }}$ ed., Butterworth-Heinemann, Oxford, UK.

Ohmura, A. (1982). Objective criteria for rejecting data for Bowen ratio flux calculations. Journal of Applied Meteorology, 21, 595-598.

http://dx.doi.org/10.1175/1520-0450(1982)021<0595:OCFRDF>2.0.CO;2

Paco, T. A., Ferreira, M. I., \& Conceicao, N. (2006). Peach orchard evapotranspiration in a sandy soil: comparison between eddy covariance measurements and estimates by the FAO 56 


\section{Macrothink}

approach. Agricultural Water Management, 85, 305-313.

http://dx.doi.org/10.1016/j.agwat.2006.05.014

Paw, U. K. T., Qiu, J., Su, H. B., Watanabe, T., \& Brunet, Y. (1995). Surface renewal analysis: a new method to obtain scalar fluxes without velocity data. Agricultural and Forest Meteorology, 74, 119-137. http://dx.doi.org/10.1016/0168-1923(94)02182-J

Suleiman, A. A., Tojo-Soler, C. M., \& Hoogenboom, G. (2007). Evaluation of FAO-56 crop coefficient procedures for deficit irrigation management of cotton in a humid climate. Agricultural Water Management, 91, 33-42. http://dx.doi.org/10.1016/j.agwat.2007.03.006

Teixeira, A. H. de C., Bastiaanssen, W. G. M., \& Bassoi, L. H. (2007). Crop water parameters of irrigated wine and table grapes to support water productivity analysis in the Sao Francisco river basin, Brazil. Agricultural Water Management, 94, 31-42.

http://dx.doi.org/10.1016/j.agwat.2007.08.001

Teixeira, A. H. de C., Bastiaanssen, W. G. M., Moura, M. S. B., Soares, J. M., Ahmad, M. D., $\&$ Bos, M. G. (2008). Energy and water balance measurements for water productivity analysis in irrigated mango trees, northeast Brazil. Agricultural and Forest Meteorology, 148, 1524-1537. http://dx.doi.org/10.1016/j.agrformet.2008.05.004

Testi, L., Villalobos, F. J., \& Orgaz, F. (2004). Evapotranspiration of a young irrigated olive orchard in southern Spain. Agricultural and Forest Meteorology, 121, 1-18. http://dx.doi.org/10.1016/j.agrformet.2003.08.005

Wang, D., \& Gartung, J. (2010). Infrared canopy temperature of early-ripening peach trees under postharvest deficit irrigation. Agricultural Water Management, 97, 1787-1794. http://dx.doi.org/10.1016/j.agwat.2010.06.014

Zarco-Tejada, P. J., Gonzalez-Dugo, V., \& Berni, J. A. J. (2012). Fluorescence, temperature and narrow-band indices acquired from a UAV platform for water stress detection using a micro-hyperspectral imager and a thermal camera. Remote Sensing of Environment, 117, 322-337. http://dx.doi.org/10.1016/j.rse.2011.10.007

\section{Copyright Disclaimer}

Copyright for this article is retained by the author(s), with first publication rights granted to the journal.

This is an open-access article distributed under the terms and conditions of the Creative Commons Attribution license (http://creativecommons.org/licenses/by/3.0/). 